\title{
Corporate Green Initiatives and Financial Performance in Malaysian Plantation Sector
}

\author{
Wang Xin Rui, Ridzwana Mohd Said, Fakarudin Kamarudin, Norhuda Abdul Rahim
}

\begin{abstract}
Adoption of green initiatives by companies is important to create healthier environment. Added with the demand from wider stakeholders, companies realise the importance of disclosing information in their corporate report. The purpose of this study is to examine the effect of green initiatives on companies' performance of plantation sector in Malaysia. Twenty-one public listed companies were selected. Content analysis was used to collect data from annual reports and sustainability reports related to information on green product, wastewater treatment technologies and energy efficiency. Data for dependent variables which are return on asset and return on equity also were obtained from annual reports. Descriptive analysis, correlation analysis and multiple regressions using SPSS were adopted to analyse the data. The results of this study reveal that energy efficiency have significant relationship with companies' financial performances whereas green product and wastewater treatment technologies show in contrary.
\end{abstract}

Index Terms: Green product, wastewater treatment technologies, energy efficiency, Malaysia

\section{INTRODUCTION}

Recently, the globe is experiencing a series of alarming environmental problems. Environmental problems such as global warming, acid rain, air pollution, urban sprawl, waste disposal, depletion of the ozone layer, water pollution, climate change and much more affect all humans, animals and nations of the world. Malaysia, as a developing country, also concerns about environmental problems given the country is striving to achieve sustainable development as a developed country [1]. According to ISO Survey 2017, the number of certifications of ISO 14001 obtained by companies in Malaysia has decrease by 2.88 per cent from 2325 to 2258 . The reduction indicates that companies in Malaysia are no longer meet the requirement of the standard of ISO 14001 and the certificates were withdrew. Nevertheless, in 2010, government of Malaysia established Malaysian Green Technology Corporation also known as GreenTech Malaysia to encourage green sustainability by companies. In recognising Green Technology as a driver for the nation

Revised Manuscript Received on November 11, 2019.

Wang Xin Rui, Faculty of Economics and Management, Universiti Putra Malaysia, Serdang, Malaysia. xinrui0824@gmail.com

Ridzwana Mohd Said, Correspondence Author, Department of Accounting and Finance, Faculty of Economics and Management, Universiti Putra Malaysia, Serdang, Malaysia. ridzwana@upm.edu.my

Fakarudin Kamarudin, Department of Accounting and Finance, Faculty of Economics and Management, Universiti Putra Malaysia, Serdang, Malaysia. fakarudin@upm.edu.my

Norhuda Abdul Rahim, Department of Accounting and Finance, Faculty of Economics and Management, Universiti Putra Malaysia, Serdang, Malaysia. huda@upm.edu.my economic growth, government of Malaysia had provided the investment tax allowance for purchase of green technology equipment and income tax exemption for green technology services companies. The purpose of tax allowance benefit is to further stimulate the green technology adoption and awareness in different sectors. Besides, it may encourage companies to invest in green technologies to improve green technology service and system providers.

As the public is very concern about environmental issues in Malaysia, the adoption of green initiatives in Malaysian public listed companies (PLCs) is important in order to reflect their efforts to protect the environment. Due to the demand for information by wider stakeholders, the only way to see how a company reacts to the environment is through disclosure of information. The awareness on the importance of environmental related information disclosure in the business community has increased. Corporate annual reports and other stand-alone reports have been used as main medium of communication with stakeholders [2].

According to Sustainable Stock Exchanges Initiative, all Main Market and ACE Market listed companies in Malaysia are required to disclose their Sustainability Statements in annual reports issued for the financial year ending on or after 31 December 2018. However, study did by Aziz, Ong, Foong, Senik and Attan [3] found that the extent of the adoption of green initiatives in Malaysian PLCs in practice is moderate. The PLCs adopt green initiatives such as waste management, recycling and saving energy, but they are not proactive. For instance, industries that require a high level of clean and healthy environment that will need to be regularly monitored by the Health Department, such as poultry industry, are aggressively taking green initiatives. In fact, the companies also adopt green initiatives if they can obtain benefits. Apart from that, profit-oriented companies give less emphasis on green initiatives as they have to weigh the associated costs and profits. Nevertheless, result by the study shows that adoption of green initiatives would significantly affect the environmental performance of PLCs and thus contribute to a better environment.

Accordingly, this study aims to examine the effect of green initiatives on companies' performance. The findings may encourage companies to adopt green initiatives and protect the environment from deterioration as well as reduce environmental damage. 


\section{Corporate Green Initiatives and Financial Performance in Malaysian Plantation Sector}

\section{LITERATURE REVIEW}

\section{Green Initiatives}

With the recent global climate change, more companies around the world emphasis on the adoption of green initiatives and to be more eco-friendly. The green initiatives may include waste management, reducing carbon emissions, developing eco-friendly products and energy saving [3]. According to Kushwaha and Sharma [4], firms are adopting different green activities such as green marketing, green supply chain management, green innovation and others. Ajike and Anjolajesu [5] also stated that many developed countries such as Johannesburg, South Africa and Rio de Janeiro, Brazil and developing countries are also adopting green initiatives to sustain their environment. According to Chen, Lai and Wen [6], green innovation is described as innovation related to green products, including energy-saving, pollution-prevention, waste recycling, or corporate environmental management. In general, green initiatives are green activities invested by companies to create better environment.

\section{Types of Green Initiatives}

There are a number of green initiatives undertaken by companies. In this study, green product, wastewater treatment technologies and energy efficiency have been chosen. These variables have been collected from a number of relevant literature and this study examined the green initiatives as one group of variables. While prior studies were largely carried out in developed countries, this study specifically focuses plantation sector in a developing country, i.e. Malaysia. The identified three green initiatives are as follows:

\section{a) Green product}

The development of green products emphasises "end-of-pipe technology" where companies are aware of environmental problems through production processes and product design. Green product is designed to minimise the use of non-renewable resources and avoid toxic materials throughout its entire life cycle. It would be the most efficient way to display green technology [7].

\section{b) Wastewater treatment technologies}

Wastewater treatment technologies can be designed to provide minimal cost sanitation and protection for environment from water reuse. The water treatment process does not only produce clean water that can be reused, but also has potential to generate other benefits. It can reduce the production of waste in a country, to produce energy and natural fertilizer by harvesting methane and collecting waste [8].

\section{c) Energy efficiency}

Energy efficiency means use or less use of energy to perform the same tasks. Energy efficiency is to reduce the energy needed to provide products and services. Based on the results of energy saving technologies, a significant amount of electricity, emissions and utility bills can be reduced by using these technologies in the industrial sector [3].

\section{Disclosure of Green Initiatives in Malaysia}

Based on research conducted by Suhardjanto, Purwanto, Ashardianti and Setiany [9], the result shows that the level of environmental disclosure in agricultural and consumer goods companies in Indonesia and Malaysia is still low. Besides, Aziz et al. [3] found the extent of the adoption of green initiatives in Malaysian PLCs in practice is moderate. In fact, Mohd Said, Lim, Senik, Yusri and Ong [10] concurred that sustainability disclosure was not a common practice among companies in Malaysia as opposed to companies in developed countries. Even the level of environmental disclosure among environmental sensitive companies in Malaysia was limited and in declarative form [11]. This may due to that the green initiatives adoption needs the companies to provide high amount of time and resources, and the expensive cost would not give return to the companies in a short-term. Therefore, emphasis on investing in green activities may be less given by companies in Malaysia as many of them aims for profitability of companies.

Yusoff and Darus [12] explored environmental reporting practices in Malaysia using questionnaire survey. The results show that business managers had taken positive steps in implementing environmental reporting practices. The study also concluded that companies conducted environmental reporting to improve their image and fulfil their responsibility in meeting the demands of stakeholders. In another study, Nik-Wan, Haliza-Asat, and Zain [13] examined the environmental reporting practice by SMEs in Malaysia. The study identified that various medium of reporting were used to disseminate environmental information. However, the result showed that the SMEs prepared simple environmental reporting which are less variety and straight forward. Some companies did involve in environmental initiatives but did not document it.

\section{Hypotheses Development}

A. Green Product

Lin, Tan and Geng [14] found that market demand is positively correlated to both green product innovation and firm performance. In addition, green product innovation performance is also positively correlated to firm performance. Besides, Ar [15] also investigated the relationship between green product innovation and firm performance. Green product involves the use of environmental friendly goods as well as the use of eco-labelling. The study concluded that green product innovation identified from the information disclosed by companies is positively correlated with financial performance. This is consistent with legitimacy theory whereby companies would disclose more voluntary information on green product to increase performance and to show the public they are doing good to the environment. Consistent with prior studies, the following hypotheses are developed: 
H1a: There is a positive relationship between green product and return on assets.

$\mathrm{H} 1 \mathrm{~b}$ : There is a positive relationship between green product and return on equity.

\section{B. Wastewater Treatment Technologies}

Wastewater treatment technology is one of the green initiatives to preserve and conserve the environment. Henriques and Catarino [16] studied on energy efficiency indicator in wastewater treatment plants for sustainable value. They concluded that wastewater treatment improves energy efficiency. Energy saving reduces cost and lead to improvement in financial performance [17]. Companies would disclose more voluntary information about green initiatives to show the public that they care the environment and to legitimize their existence in the public. Accordingly, the hypotheses are developed:

$\mathrm{H} 2 \mathrm{a}$ : There is a positive relationship between wastewater treatment technologies and return on assets.

$\mathrm{H} 2 \mathrm{~b}$ : There is a positive relationship between wastewater treatment technologies and return on equity.

\section{Energy Efficiency}

Song et al. [17] examined the relationship between environmental management and financial performance of companies in China. Environmental management such as reusing energy improves production efficiency can decrease product costs. Thus, company improves its operation financial performance with a reduction in cost. The result shows that environmental management is positively related to the performance of company in the future year but not the current year. Besides, another study by Fan, Pan, Liu and Zhou [18] concluded that energy efficiency is positively related with performance of company. The disclosure of information on environmental management increases the likelihood being accepted by the public as the public are presently interested on issues related to environment and sustainability. This enables the companies to legitimize themselves in the society. According to the study, the following hypotheses are developed:

H3a: There is a positive relationship between energy efficiency and return on assets.

$\mathrm{H} 3 \mathrm{~b}$ : There is a positive relationship between energy efficiency and return on equity.

Independent Variables

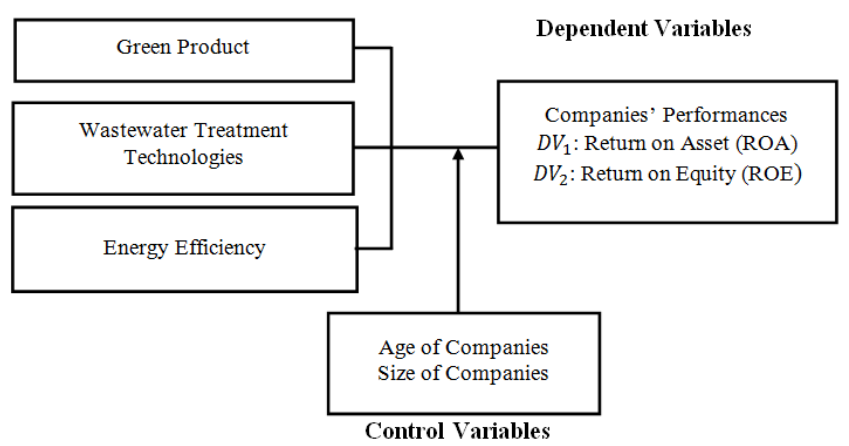

Fig. 1: Conceptual framework

Fig. 1 above shows the conceptual framework used to explain the relationship between the independent variables (Green product, Wastewater treatment technologies and Energy efficiency) and the dependent variables (Return on asset and Return on equity). The control variables are age and size of companies. Legitimacy theory argued that companies disclose information on green initiatives to legitimize their existence in the market. To engage with the various stakeholders, one of the ways is through disclosure of voluntary information such as environmental and green information. Thus, companies will disclose more in order to be accepted for operation by wider stakeholders.

\section{RESEARCH DESIGN}

This study used companies' annual reports and sustainability reports to extract data which obtained from Bursa Malaysia website and selected companies' website. Annual reports and stand-alone sustainability reports were used as sources of information because most of the information on green initiatives adoption is disclosed in these reports. In addition, these reports are easily accessible and provide comprehensive information on companies' financial and non-financial information [19].

The population of this study involved a total of 44 PLCs in plantation sector that were listed on the both Main and Ace market of Bursa Malaysia as of April 2019. This sector has been chosen because it is claimed as an environmentally sensitive industry. It is expected that companies in environmentally sensitive industries will engage in activities that affect the environment and disclose comprehensive information about the environment [20]. Five consecutive periods from 2013 to 2017 were used in this study. Twenty-one companies were selected from 44 companies, which accounts for approximately 47.73 percent of the population. The sample is selected after removing companies that have not disclosed any information on green product, wastewater treatment technologies and energy efficiency in the reports throughout the five years.

The state of green initiatives among public listed companies in Malaysia were determined through content analysis by quantitatively counting the number of sentences of green initiatives information in the annual report. According to Parveen and Showkat [21], content analysis is an interpretation of what is contained (content) in a message. It is a research technique for subjective interpretation of the content of text data through systematic classification process of coding and identification of themes or patterns. The green initiatives disclosure information were then tabulated using SPSS.

In addition, multiple regression analysis was used to examine the relationship between green initiatives and companies' financial performance. According to Öge [22], multiple regression analysis is widely used when several variables are involved and have 


\section{Corporate Green Initiatives and Financial Performance in Malaysian Plantation Sector}

significant towards target value. Hence, in this study, multiple regression analysis was used to explain the relationship between independent variables and dependent variables. The models involved in this study are as follows:

Model 1:

$$
\mathrm{ROA}=\alpha+\beta \mathrm{GP}+\beta \mathrm{WWTT}+\beta \mathrm{EE}+\beta \mathrm{AC}+\beta \mathrm{SC}+\varepsilon
$$

Model 2:

$$
\mathrm{ROE}=\alpha+\beta \mathrm{GP}+\beta \mathrm{WWTT}+\beta \mathrm{EE}+\beta \mathrm{AC}+\beta \mathrm{SC}+\varepsilon
$$

Where:

$\alpha \quad=$ Intercept of the variables

$\beta \quad=$ Coefficient of the regression

$\varepsilon \quad=$ Error term

ROA $=$ Return on asset

ROE = Return on equity

$\mathrm{GP}=$ Green product

WWT $=$ Wastewater treatment technologies

$\mathrm{EE} \quad=$ Energy efficiency

$\mathrm{AC} \quad=$ Age of companies

$\mathrm{SC} \quad=$ Size of companies

This study consists two dependent variables which are return on asset (ROA) and return on equity (ROE). The independent variables are the green initiatives which are green product, wastewater treatment technologies and energy efficiency. The control variables are age and size of companies. Green initiatives were measured based on the disclosure level about green initiatives information in the companies' reports. Content analysis to quantitatively identify the extensiveness of green initiative disclosure was used by counting the number of sentences of each type of green initiatives.

\section{ANALYSIS OF FINDINGS}

\section{A. Descriptive Analysis}

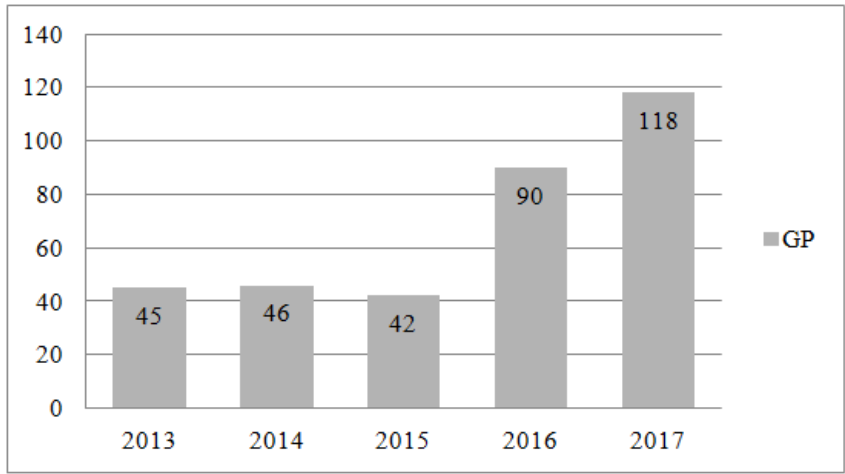

Diagram 1: Disclosure on green product

Diagram 1 shows the disclosure on green product in the annual reports and sustainability reports by the 21 public listed companies in plantation sector from year 2013 to year 2017. The diagram shows that in year 2015, the disclosure level on green product is the lowest with 42 sentences have been disclosed. In year 2013 and 2014, the disclosure on green product is 45 and 46 sentences respectively. Then, the information disclosure has a huge increase in year 2016 with a total number of 90 sentences. The year 2017 marks the highest level within the 5 years with 118 sentences has been disclosed in companies' reports.

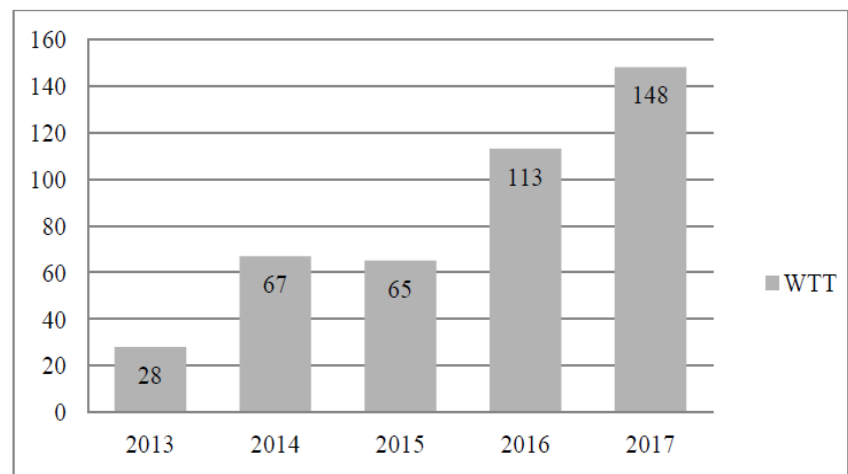

Diagram 2: Disclosure on Wastewater Treatment Technologies

Diagram 2 shows that in year 2013, the disclosure level on wastewater treatment technologies is the lowest with the total number of 28 sentences have been disclosed. In year 2014 and 2015, the disclosure on wastewater treatment technologies increases to 67 and 65 sentences respectively. Besides, the disclosure continues to increase in year 2016 and 2017 with the total number of 113 sentences and 148 sentences. The increase in disclosure shows that the companies are more concern in the wastewater treatment technologies for the environment overtime.

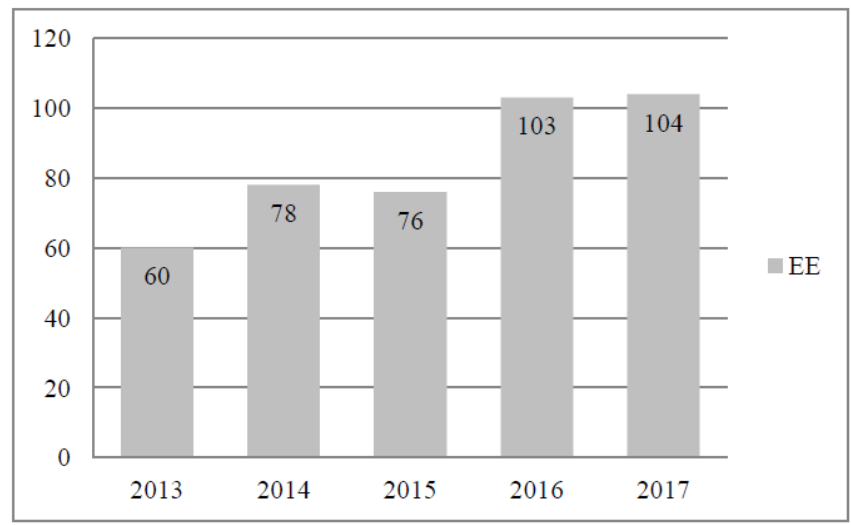

Diagram 3: Disclosure on energy efficiency

Diagram 3 reveals that in year 2013, the disclosure level on energy efficiency is the lowest with the total number of 60 sentences have been disclosed. In year 2014 and 2015, the disclosure has increased to 78 and 76 sentences respectively. After that, the disclosure continues to rise in year 2016 with a total number of 103 sentences. In year 2017, the disclosure on energy efficiency is 104 sentences. 
Table 1: Descriptive statistics

\begin{tabular}{|l|c|c|c|c|c|c|}
\hline & Min. & Max. & Mean & $\begin{array}{c}\text { Std. } \\
\text { Deviation }\end{array}$ & Skewness & Kurtosis \\
\hline GP & 0 & 19 & 3.25 & 4.11 & 1.98 & 4.45 \\
\hline WWTT & 0 & 37 & 4.01 & 6.03 & 2.38 & 8.05 \\
\hline EE & 0 & 28 & 4.01 & 6.03 & 2.01 & 3.83 \\
\hline AC & 6 & 107 & 45.52 & 24.90 & 0.91 & 0.62 \\
\hline SC & 18.84 & $\begin{array}{c}23.9 \\
0\end{array}$ & 21.60 & 1.13 & 0.08 & 0.46 \\
\hline ROA & -7.01 & $\begin{array}{c}18.2 \\
6\end{array}$ & 4.30 & 3.90 & 0.52 & 1.41 \\
\hline ROE & -21.69 & $\begin{array}{c}34.1 \\
4\end{array}$ & 5.89 & 6.65 & -0.13 & 4.69 \\
\hline
\end{tabular}

Normality test has been carried out in this study to determine whether the data used are well-modelled. Kline [23] argued that the absolute value of Skewness more than 3 and Kurtosis value greater than 10 may indicate a problem while above 20 may indicate a more serious problem. Therefore, the author suggested that the absolute values of Skewness and Kurtosis should not be greater than 3 and 10 . Based on this suggestion, Skewness and Kurtosis of all variables in this study considered acceptable.

Based on Table 1, the dependent variable, return on asset in Model 1 has a mean of 4.30 with a standard deviation of 3.90. The minimum and maximum values are -7.01 and 18.26 respectively. Next, return on equity in Model 2 has a mean of 5.89 with a standard deviation of 6.65 . The minimum and maximum values are -21.69 and 34.14 respectively. The independent variables in this study are green product, wastewater treatment technologies and energy efficiency. All of the independent variables have the lowest minimum value which is 0 . The highest maximum value is wastewater treatment technologies with 37 , followed by energy efficiency with 28 and green product with 19 . The mean and standard deviation for green product is 3.25 and 4.11. For wastewater treatment technologies, it has a mean of 4.01 and standard deviation of 6.03. Besides, the mean and standard deviation for energy efficiency is 4.01 and 6.03 respectively. The control variables in this study are age and size of company. The minimum value for age of company is 6 and the maximum value is 107 whereas for the size of company is 18.84 and 23.90 respectively. The mean values for age and size of company are 45.52 and 21.60, respectively.

\section{B. Correlation Analysis}

Spearman's Rank correlation coefficient was used to summarise the strength and direction (negative or positive) of a relationship between two variables. There is a strong positive correlation if $r$ value closet to +1.0 , while when $r$ value closet to -1.0 , it will indicate a strong negative correlation.

Table 2: Summary of correlation analysis (Model 1)

\begin{tabular}{|l|c|c|c|c|c|c|}
\hline Variables & ROA & GP & WWTT & EE & AC & SC \\
\hline ROA & 1.000 & & & & & \\
\hline GP & 0.013 & 1.000 & & & & \\
\hline WWTT & 0.209 & 0.489 & 1.000 & & & \\
\hline
\end{tabular}

Table 2 presents summary of correlation analysis for model 1. Based on the table, return on asset has a weak positive relationship with wastewater treatment technologies (0.209), energy efficiency (0.339) and size of company (0.137), whereas a negligible correlation with green product $(0.013)$ and age of company (-0.011). In addition, green product has a moderate positive relationship with wastewater treatment technologies with $\mathrm{r}=0.489$, while a weak positive relationship with energy efficiency and size of company with $r=0.300$ and 0.250 respectively. Green product also has a weak negative relationship with age of company which is -0.193 . Besides, wastewater treatment technologies has a moderate positive relationship with energy efficiency and size of company with 0.518 and 0.469 . Wastewater treatment technologies and energy efficiency also have a weak negative relationship with age of company which are -0.303 and -0.314. Moreover, energy efficiency has a moderate positive relationship with size of company with 0.483 . Age of company has a negligible correlation with size of company with -0.098 .

Table 3: Summary of correlation analysis (Model 2)

\begin{tabular}{|l|r|r|r|r|r|r|}
\hline Variables & \multicolumn{1}{c|}{ ROE } & \multicolumn{1}{c|}{ GP } & WWTT & EE & AC & SC \\
\hline ROE & 1.000 & & & & & \\
\hline GP & 0.004 & 1.000 & & & & \\
\hline WWTT & 0.248 & 0.489 & 1.000 & & & \\
\hline EE & 0.384 & 0.300 & 0.518 & 1.000 & & \\
\hline AC & -0.018 & -0.193 & -0.303 & -0.314 & 1.000 & \\
\hline SC & 0.305 & 0.250 & 0.469 & 0.483 & -0.098 & 1.000 \\
\hline
\end{tabular}

Table 3 shows summary of correlation analysis for model 2. Return on equity has a weak positive relationship with energy efficiency, wastewater treatment technologies and size of company which are $r=0.384,0.248$ and 0.305 , whereas a negligible correlation with green product and age of company, which are 0.004 and -0.018 . Furthermore, green product has a moderate positive relationship with wastewater treatment technologies and a weak positive relationship with energy efficiency and size of company with $r=0.489,0.300$ and 0.250. Green product also has a weak negative relationship with age of company with -0.193 . Moreover, wastewater treatment technologies has a moderate positive relationship with energy efficiency and size of company with $r=0.518$ and 0.483 . Wastewater treatment technologies also has a weak negative relationship with age of company with $r$ $=-0.303$. Furthermore, energy efficiency has a weak negative relationship with age of company $(-0.314)$ and a moderate positive relationship with size of company (0.483). Age of company has a negligible correlation with size of company with -0.098 . 


\section{Multiple Regression Analysis}

\section{Green initiatives and return on assets}

From table 4, it shows that the adjusted R2 of model 1 is very small with 0.086 . It indicates that only $8.6 \%$ of the variation dependent variable (return on asset) is defined by the independent variables. Nevertheless, the coefficient of energy efficiency is positive and significant with the p-value of $<0.05$ ( $\mathrm{B}=2.055, \mathrm{p}=0.042)$. This implies that energy efficiency influence financial performance of companies, measured by return on assets. However, the coefficient of green product is negative and not significant with the $\mathrm{p}$-value of $>0.05(\mathrm{~B}=-0.403, \mathrm{p}$-value $=0.688)$. In addition, the coefficient of wastewater treatment technologies is positive and not significant with the $\mathrm{p}$-value of $>0.05$. ( $\mathrm{B}=0.299$, p-value $=0.766)$. Thus, green products initiatives and wastewater treatment technologies do not affect plantation companies' financial performance in this study.

Table 4: Summary of multiple regression analysis (Model 1)

\begin{tabular}{|c|c|c|c|c|c|}
\hline \multirow[t]{2}{*}{ Model } & \multirow[t]{2}{*}{$\begin{array}{l}\text { Variable } \\
\mathrm{s}\end{array}$} & \multicolumn{2}{|c|}{$\begin{array}{l}\text { Unstandardized } \\
\text { Coefficients }\end{array}$} & \multirow[t]{2}{*}{$\mathrm{t}$-value } & \multirow[t]{2}{*}{$\begin{array}{l}\mathrm{p} \text {-val } \\
\text { ue }\end{array}$} \\
\hline & & $\beta$ & $\begin{array}{l}\text { Std. } \\
\text { Error }\end{array}$ & & \\
\hline \multirow{6}{*}{1} & Constant & -4.783 & 8.358 & -0.572 & 0.568 \\
\hline & GP & -0.045 & 0.111 & -0.403 & 0.688 \\
\hline & WWTT & 0.025 & 0.084 & 0.299 & 0.766 \\
\hline & $\mathrm{EE}$ & 0.170 & 0.083 & 2.055 & $\begin{array}{c}0.042 \\
*\end{array}$ \\
\hline & $\mathrm{AC}$ & 0.042 & 0.016 & 2.708 & $\begin{array}{c}0.008 \\
*\end{array}$ \\
\hline & $\mathrm{SC}$ & 0.302 & 0.393 & 0.768 & 0.444 \\
\hline \multicolumn{6}{|c|}{$\mathrm{R}^{2}=0.130$} \\
\hline \multicolumn{6}{|c|}{ Adjusted $R^{2}=0.086$} \\
\hline
\end{tabular}

\section{Green initiatives and return on equity}

From table 5, it shows that the adjusted R2 of model 2 is 0.155 . It indicated that only $15.5 \%$ of the variation dependent variable (return on equity) is defined by the independent variables. Apart from that, the coefficient of energy efficiency is positive and significant with the p-value of $<0.05$. ( $B=2.243, p=0.027)$. Similar to the above result, energy efficiency affects companies' financial performance, measured by return on equity. However, the coefficient of green product is negative and not significant with the $\mathrm{p}$-value of $>0.05(\mathrm{~B}=-0.444, \mathrm{p}$-value $=0.658)$. In addition, the coefficient of wastewater treatment technologies is negative and not significant with the $\mathrm{p}$-value of $>0.05$. $(\mathrm{B}=-0.193$, $\mathrm{p}$-value $=0.847)$. Thus, both green initiatives do not affect companies return on equity revealed in this study.

Table 5: Summary of multiple regression analysis (Model 2)

\begin{tabular}{|c|c|c|c|c|c|}
\hline \multirow[t]{2}{*}{ Model } & \multirow[t]{2}{*}{ Variables } & \multicolumn{2}{|c|}{$\begin{array}{c}\text { Unstandardized } \\
\text { Coefficients }\end{array}$} & \multirow[t]{2}{*}{$\begin{array}{c}\text { t-valu } \\
\mathrm{e}\end{array}$} & \multirow[t]{2}{*}{ p-value } \\
\hline & & $\beta$ & $\begin{array}{l}\text { Std. } \\
\text { Error }\end{array}$ & & \\
\hline \multirow{2}{*}{2} & Constant & -29.909 & 13.698 & -2.183 & 0.031 \\
\hline & GP & -0.081 & 0.181 & -0.444 & 0.658 \\
\hline
\end{tabular}

\begin{tabular}{|l|l|c|c|c|c|}
\hline & WWTT & -0.026 & 0.137 & -0.193 & 0.847 \\
\cline { 2 - 6 } & EE & 0.304 & 0.136 & 2.243 & $0.027^{*}$ \\
\cline { 2 - 6 } & AC & 0.055 & 0.026 & 2.152 & $0.034^{*}$ \\
\cline { 2 - 6 } & SC & 1.502 & 0.644 & 2.332 & $0.022^{*}$ \\
\hline \multicolumn{6}{|c|}{$\mathrm{R}^{2}=0.196$} \\
\hline \multicolumn{7}{|c|}{ Adjusted $\mathrm{R}^{2}=0.155$} \\
\hline
\end{tabular}

\section{DISCUSSION AND CONCLUSION}

This study examined the current state of disclosure on green initiatives by companies in plantation sector in Malaysia. The results revealed that the disclosure level in year 2013 is low but it is increasing throughout the five years. In year 2017, it has the highest disclosure level within the 5 years, yet considered to be at a moderate level. The finding is consistent with prior studies on disclosure level on green initiatives in Malaysia PLCs (Aziz et al., [3]; Mohd Said et al., [11]; Nor, Bahari, Adnan, Kamal, \& Ali, [24]; Suhardjanto et al., [9]; Yusoff \& Darus, [12]). Generally, the authors concluded that the level of environmental and green information disclosure in Malaysia is still at moderate to low. The plausible reason for low green information disclosure by companies in Malaysia may due to the high committed costs to invest in green initiatives and reporting such information to wider stakeholders. However, the findings indicate that even the information is not so aggressively disclosed, some companies are proactive in disclosing information related on green initiatives. This is consistent with the legitimacy theory as companies with a strong environmental relevance such as companies in plantation sector, are more committed to the disclosure on green initiatives to legitimize their existence and to be accepted by wider stakeholders. Nevertheless, the findings show an increasing trend of disclosure on green initiatives by companies in Malaysian plantation sector.

Besides that, this study also examined the effect of green initiatives on companies' financial performance. The results reveal that one of the green initiatives which are energy efficiency influences the financial performance positively, but in contrast to green product and wastewater treatment technologies. Malaysian PLCs in plantation sector emphasis more on energy efficiency than green product and wastewater treatment technologies as the companies realize investing more in green technology related to energy efficiency would benefits them in future. The results would give impact on companies' decisions to improve their green activities in energy saving in order to boost their financial performance. Increasing energy efficiency can reduce energy costs. Keeping low cost is important for company to make more profit as they can earn more with lower costs. The result is consistent with the existing research (for example, Song et al., [17]; Fan et al., [18])

In contrast, the result also revealed the other two green initiatives - green product and wastewater treatment technologies did not affect financial performance of companies. This may due to that the impact of environmental initiatives can only be seen in longer term than 5 years period. Although the 
companies are becoming more proactive in adopting green initiatives as disclosed in their reports, both did not affect the short-term performance of companies, measured by ROA and ROE. This is consistent with studies carried out by Aguilera-Caracuel and Ortiz-de-Mandojana [25] and Cai and $\mathrm{Li}$ [26]. Green initiatives such as investing in wastewater treatment technologies require high costs and risks as it might not bring expected profits to the company.

This study has several implications. Firstly, legitimacy theory was revealed whereby most of the PLCs adopt green initiatives to legitimize themselves in society and the local community as reflected in the disclosure of green information in annual reports and sustainability reports. Companies in plantation sector known as environmental sensitive companies are expected by the public to actively involve in the adoption of green initiatives to preserve and conserve the environment. Next, the green initiatives adopted by the companies are disclosed in the annual reports or stand-alone sustainability reports so that the stakeholders can easily access it. The companies disclose such information not only to comply with the rules and regulations but also to provide understanding to the public on how they care for the environment.

The findings presented in this study also contribute to the interest of community. If companies use energy efficiently in their production process, it does not only lesser the production costs and indirectly may increase companies' profits. Indeed, with limited natural resources available to be used, energy efficiency invested by companies is a way of managing and limiting energy consumption and to ensure there is energy left for future generations. Additionally, lesser carbon emissions are pumped into the environment which may also promise sustainability of the globe.

The authors acknowledge that the present study has its share of limitations. First, this study only focused on companies in plantation sector in Malaysia. Thus, the results may be differ if similar study is extended to other sectors. Next, the small number of sample in this study may affect results of the analysis. From the other point of view, it implies that many companies in plantation sector in Malaysia are still at infant stage to invest in green initiatives. This is demonstrated when less than $50 \%$ of the companies disclosed green information throughout the five years of study.

The results and limitations highlighted above bring to a few suggestions for future research. Firstly, future study may include other environmental sensitive sectors in order to enhance the findings of this study. A broader population is suggested also to obtain detailed information on green initiatives in other sectors. Besides, future studies are suggested to collect data in various forms. Although annual reports and sustainability reports disclose most of the information, some information on green initiatives may be disclose in other medium such as social media, companies' websites and newspapers.

\section{ACKNOWLEDGEMENT}

This research work was funded by the Universiti Putra
Malaysia Grant (UPM/700-2/1/GP/2017/9573000).

\section{REFERENCES}

1. N. Mokthsim, \& K. O. Salleh. (2014). Malaysia's efforts towards achieving a sustainable development: Issues, challenges and prospects. Procedia Social and Behavioral Sciences. [Online]. 120, pp. 120, 299-307. doi: 10.1016/j.sbspro.2014.02.107

2. F. Carreira, A. Damião, R. Abreu, \& F. David, "Environmental disclosure: From the accounting to the report perspective," [Proceedings of the $16^{\text {th }}$ International Conference on Enterprise Information Systems (ICEAS-2014), April, 2014, Lisbon]. doi: 10.5220/0004973604960501

3. E. A. Abdelaziz, R. Saidur, \& S. Mekhilef (2011). A review on energy saving strategies in industrial sector. Renewable and Sustainable Energy Reviews. [Online]. 15, pp. 150-168. doi: 10.1016/j.rser.2010.09.003

4. G. S. Kushwaha, \& N. K. Sharma. (2016). Green initiatives: A step towards sustainable development and firm's performance in the automobile industry. Journal of Cleaner Production. [Online]. 121, pp. 116-129. doi: 10.1016/j.jclepro.2015.07.072

5. S. Ajike, \& A. Anjolajesu. (2016). Examining the Lagos green initiative: A case study of Kosofe local government. International Journal of Sustainable Land Use and Urban Planning. [Online]. 3(3), pp. 1-7. doi: 10.24102/ijslup.v3i3.646

6. Y-S. Chen, S-B. Lai, \& C. T. Wen. (2006). The influence of green innovation performance on corporate advantage in Taiwan. Journal of Business Ethics. [Online]. 67(4), pp. 331-339. doi: 10.1007/s10551-006-9025-5

7. Y. K. Yan, \& R. Yazdanifard. (2014). The concept of green marketing and green product development on consumer buying approach. Global Journal of Commerce \& Management Perspective. [Online]. 3(2), pp. 33-38. Available:

https://www.longdom.org/articles/the-concept-of-green-marketing-and-gree n-product-development-on-consumer-buying-approach.pdf

8. A. Dakkak. (2018, March 8). Wastewater treatment process and its benefits. [Online]. Available: https://www.ecomena.org/wastewater-treatment/

9. D. Suhardjanto, Purwanto, D. Ashardianti, \& E. Setiany. (2018) Environmental disclosure in agricultural sector and consumer goods annual report (comparison between Indonesia and Malaysia). Review of Integrative Business and Economics Research. [Online]. 7(4), pp. 203-215. Available: https://sibresearch.org/uploads/3/4/0/9/34097180/riber_7-s4_16_k18-160 203-215.pdf

10. R. Mohd Said, T. T. Lim, R. Senik, Y. Yusri, \& T. S. Ong. (2015). The state of sustainability disclosure and effects on companies' financial performance. Pertanika Journal of Social Sciences \& Humanities. [Online]. 23(S), pp. 99-118.

11. R. Mohd Said, L. K. Lee, R. Senik, Y. Yusri. (2016). Quantity and Quality of Environmental Disclosure by Environmental Sensitive Companies in Malaysia. International Business Management. [Online]. 10(18), pp. 4342-4350. Available: http://psasir.upm.edu.my/id/eprint/53707/

12. H. Yusoff, \& F. Darus. (2012). Environmental reporting practices in Malaysia: Is it a mechanism for corporate accountability and stakeholder engagement?. Malaysian Accounting Review. [Online]. 11(2), pp. 137-159.

13. N. Z. Nik-Wan, S. Haliza-Asat, \& M. M. Zain. "Environmental reporting practice by SMEs in Malaysia," [Proceedings of the Global Conference on Business and Economics Research (GCBER-2017), August, 2017, Selangor]. Available: https://econ.upm.edu.my/content/environmental_reporting_practice_by_sm es_in_malaysia-35593? $\mathrm{L}=\mathrm{en}$

14. R. Lin, K. Tan, \& Y. Geng. (2013). Market demand, green product innovation and firm performance: evidence from Vietnam motorcycle industry. Journal of Cleaner Production. [Online]. 40, pp. 101-107. doi: 10.1016/j.jclepro.2012.01.001

15. I. M. Ar. (2012). The impact of green product innovation on firm performance and competitive capability: The moderating role of managerial environmental concern. Procedia - Social and Behavioral Science. [Online]. 62, 854-864. doi: 10.1016/j.sbspro.2012.09.144

16. J. Henriques, \& J. Catarino. (2016). Sustainable value - An energy efficiency indicator in wastewater treatment plants. Journal of Cleaner Production. [Online]. 142(1), pp. 323-330, doi: 10.1016/j.jclepro.2016.03.173

17. H. Song, C. Zhao, \& J. Zeng. (2017). Can environmental management improve financial performance: An empirical study of A-shares listed companies in China. Journal of Cleaner Production. [Online]. 141, pp. 1051-1056. doi:10.1016/j.jclepro.2016.09.105 


\section{Corporate Green Initiatives and Financial Performance in Malaysian Plantation Sector}

18. L. W. Fan, S. J. Pan, G. Q. Liu, \& P. Zhou. (2017). Does energy efficiency affect financial performance? Evidence from Chinese energy-intensive firms. Journal of Cleaner Production. [Online]. 151, pp. 53-59. doi: 10.1016/j.jclepro.2017.03.044

19. International Financial Reporting Standards (IFRS). (2017). Better communication in financial reporting: Making disclosures more meaningful. London: IFRS Foundations.

20. H. Yusoff, S. H. Kamaruddin, \& E. K. Ghani, E. K. (2018). Environmental reporting practices of top public listed companies: Analyzing pre-post CSR framework. Indonesian Journal of Sustainability Accounting and Management. [Online]. 2(1), pp. 50-64. Available: http://www.unpas.id/index.php/ijsam/article/viewFile/48/31

21. H. Parveen, \& N. Showkat. (2017, July). Content Analysis. [Online]. Available:https://www.researchgate.net/publication/318815342_Content_ Analysis

22. I. F. Öge. (2017). Prediction of cementitious grout take for a mine shaft permeation by adaptive neuro-fuzzy inference system and multiple regression. Engineering Geology. [Online]. 228, pp. 238-248. doi: 10.1016/j.enggeo.2017.08.013

23. R. B. Kline. (2011). Principles and practice of structural equation modelling (3rd ed.). New York, NY: The Guildford Press.

24. N. M. Nor, N. A. S. Bahari, N. A. Adnan, S. M. Q. A. S. Kamal, \& I. M. Ali. (2016). The effects of environmental disclosure on financial performance in Malaysia. Procedia Economics and Finance. [Online]. 35, pp. 117-126. doi: $10.1016 / \mathrm{S} 2212-5671(16) 00016-2$

25. J. Aguilera-Caracuel, \& N. Ortiz-de-Mandojana. (2013). Green innovation and financial performance: An institutional approach. Organization \& Environment. [Online]. 26(4), pp. 365-385. doi $10.1177 / 1086026613507931$

26. W. Cai, \& G. Li. (2018). The drivers of eco-innovation and its impact on performance: Evidence from China. Journal of Cleaner Production. [Online]. 176, pp. 110-118. doi: 10.1016/j.jclepro.2017.12.109

\section{AUTHORS PROFILE}

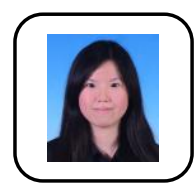

Wang Xin Rui, Ms. Wang Xin Rui graduated with Bachelor of Accountancy from Faculty of Economics and Management, University Putra Malaysia. She is currently pursuing professional qualification as an Association of Chartered Certified Accountants (ACCA). She can be contacted by her email: xinrui0824@gmail.com

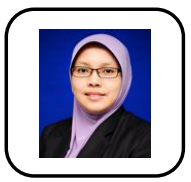

\section{Ridzwana Mohd Said}

Asssociate Professor Dr. Ridzwana obtained her PhD from International Islamic University Malaysia (IIUM). She is presently a senior lecturer at the Department of Accounting and Finance, Faculty of Economics and Management, Universiti Putra Malaysia. Her research interests include Management Accounting, Social and Environmental Reporting, and Sustainability Reporting. She has published in several journals such as Journal of Cleaner Production, Social Responsibility Journal and International Journal of Economics and Finance, to name a few. She can be contacted by her email: ridzwana@upm.edu.my

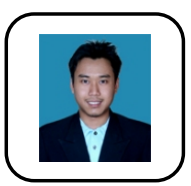

\section{Fakarudin Kamarudin}

Dr. Fakarudin graduated with $\mathrm{PhD}$ from Graduate School of Management, Universiti Putra Malaysia. He is presently a senior lecturer at the Department of Accounting and Finance, Faculty of Economics and Management, Universiti Putra Malaysia. He has published in several high impact international journals including Engineering Economics, Ekologi and Economic Computation and Economic Cybernatics Studies and Research. $\mathrm{He}$ can be contacted by his email: fakarudin@upm.edu.my

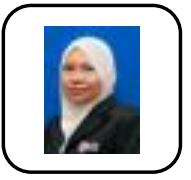

\section{Norhuda Abdul Rahim}

Dr. Norhuda holds her PhD from University of Stirling, Scotland, United Kingdom. Currently she is a senior lecturer at the Department of Accounting and Finance, Faculty of Economics and Management, Universiti Putra Malaysia. Her area of interest includes securities issuance, capital market, event study, and corporate finance related studies. Her research works have been published in several journal including European Journal of Finance, Pertanika Journal of Social Science and Humanities and Jurnal Ekonomi. She can be reached at huda@upm.edu.my 